\title{
Supracondylar Fracture of the Femur Fracture after Total Knee Arthroplasty
}

\author{
by \\ Eisuke Shono, Michiya Hara, Mituyoshi Kanbara \\ Koji Kuroda and Nahoto Takagishi \\ Department of Orthopedic Surgery, School of Medicine \\ Fukuoka University, Fukuoka814-01, Japan
}

\begin{abstract}
Summary
Total knee replacement (TKR) is now being used as a useful means of improving Activities of daily living (A. D. L.) in rheumatoid arthritis. Unfortunately however, loosening and infection as late complications of surgeryhave recently become of concern. Few reports on supracondylar fractures of the femur as another possible delayed compli-cation of TKR have been made so far in the Japanese literature. We recently ex-perienced a case of supracondylar fracture of the femur occurring 1 year after bilateral TKR, in which fixation of the fragments with the rush pins proved to be effective. It was considered useful to delineate this case in some detail and the necessity for due attention to be paid to supracondylar fractures of the femur as likely complications of TKR is indicated.
\end{abstract}

\section{Introduction}

Suoracondylar fractures of the femur following total knee arthroplasty with a nonhinged-type prosthesis is relatively uncommon. Merkel and associates ${ }^{1)}$ reported an incidence of $0.54 \%$ or so in 5233 TKR cases at the Mayo Clinic. Few reports of this complication have been made in Western Countries, that by Fujimori et al. ${ }^{2)}$ is the only report available to date in Japan. No therapeutic policy has been established for this fracture. We found fixation with the rush pins effective in treatment in our case, which will be described have with some reference to relevant literature.

\section{Case Report}

Patient : A 50-year-old female Chief complaint: Pain in the supracondylar region of the right femur. Family history: Not remarkable.

\section{Height : $149 \mathrm{~cm} \quad$ Body weight : $58 \mathrm{~kg}$}

History of present illness: The patient consulted us with polyarticular pain in June 1977. Under the diagnosis of RA she was started on drug therapy (gold, NSAID). However, intense pain in both knees persisted and $\mathrm{x}$-ray findings were of stage IV. TKR was per-formed bilaterally and simultaneously on January 12, 1989. The Range of motion (R. O. M.) at the time of discharge was $90^{\circ}$ flexion to $0^{\circ}$ full extension in both knees (Fig. 1). The patient tripped over the guilt mattress sheers on and sustained an injuryon December 10, 1989 and was subsequently admitted to the

Key words: Total Knee Replacement, Rheumatoid Arthritis, Supracondylar Fracture, Yamamoto Mark III 


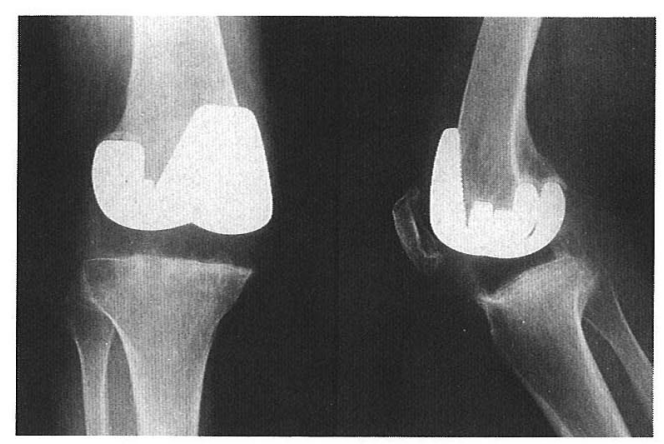

Fig 1 T. K. R. performed bilateral and simultaneously. The R. O. M. at discharge was $90^{\circ}$ flexion to $0^{\circ}$ extension in both knee.

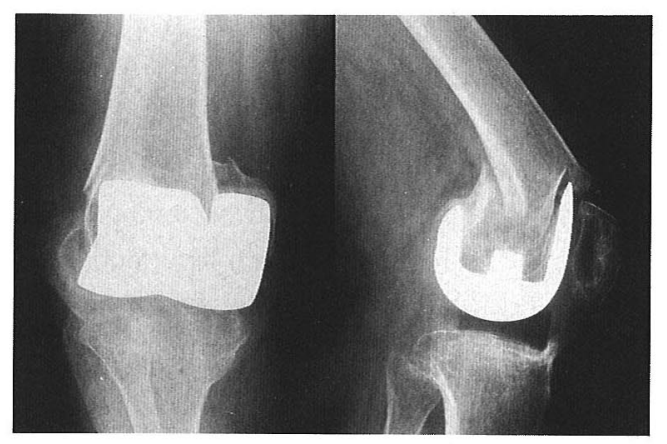

Fig 2 Supracondylar fracture of the right femur occurred 1 year after T.K. R.

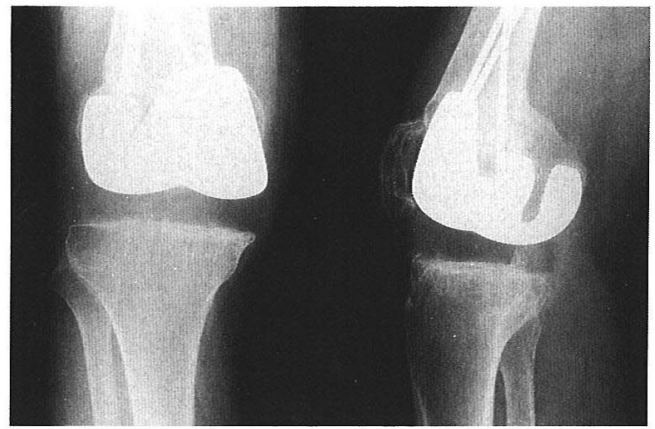

Fig 3 The R. O. M. was $60^{\circ}$ flextion to $5^{\circ}$ extension 10 months postoperatively. The bone union was excellent.

hospital with the afore-mentioned chief complaint (Fig 2). The R. O. M. of her right knee immediately before the injury was $70^{\circ}$ flexion and $5^{\circ}$ extention. Under the diagnosis of supracondylar fracture of the right femur she underwent bone fixation fusion with the rush pins on December 20 of the same year. Passive motion was initiated 5 weeks postoperatively and weight-bearing 11 weeks after operation. She was dis-charged with a single stick at 15 weekspostoperatively. The R. O. M. at dis-

charge was $55^{\circ}$ flexion to $10^{\circ}$ extention. The R. O. M. increased $60^{\circ}$ flexion to $5^{\circ}$ extension $40^{\circ}$ weeks postoperatively.

\section{Discussion}

Various types of prosthesis have recently been used in TKR. The relatively frequent postoperative complications documented so far are loosening and infection, and supracondylar fracture of the femur as such has been rarely reported.

Concerning the stiology of this complication Hirsh et al. ${ }^{3)}$ stressed the importance of bone atrophy. Sisto ${ }^{4)}$ and other authors ${ }^{1)}$ implicate breakdown of cortical bone on the anterior aspect of the distal femur caused by TKR as a major etiological factor. In the present case, the patient was rheumatoid arthritis and had advanced osteoporosis due to long-standing disease and prolonged rheumatoid activity, even though she had not been placed on an oral corticosteroid regimen. The lack of will to participate in a rehabilitation program, the decreased R. O. M. at the time of injury and disuse are considered factors that might precipitate fracture by some trivial mechanism that causes stress to be exerted on the anterior aspect of thedistal femur above the TKR component. It should be noted that these unfavorable conditions are satisfied in most RA cases and, moreover, the patient' 
s weight may also have to be taken in to consideration. Fixation of the fragments which is the most important part of treatment for supracondylar fractures of the femur may reportedly be accomplished either conservatively or by open procedure. Mooney $\mathrm{rt}$ al. ${ }^{5}$ used traction and a cast brace with good results. However, a drawback of this procedure may be malunion or nonunion and decrease R. O. M. Sisto et al. ${ }^{4)}$, performing plationg by AO technique or external fixation, reported that better results were obtained by these procedures than by conservative treatment. Since, however, the application of plates necessarily entails extensive direct involvement of bones, this procedure may increase the risk of infection and may also give rise to component loosening. Since fixation with screws is difficult to perform or even infeasible in the presence of severe osteoporosis, it would seen that external fixation is a reasonable option depending upon the site of fracture.

Nielsen et al. ${ }^{6}$ found fixation with the rush pins effective in fixate the fragments in place. In the present case also, fixation with the rush pins proved satis-factory, aside from some delay in bone union. This procedure, being less invasive, appears to be recommendable on conditionthat malalignment is cautiously guarded against. The R. O. M. in our case was reduced by $10 \%$ or so postoperatively as in other reported cases. Continous passive motion was more effective in this case ${ }^{7}$.

\section{Summary}

A case of supracondylar fracture of the femur, a relatively rare complication of TKR, was reported with some reference to relevant literature with emphasis etiology and treatment. The rush pins were effective to fixate in our case.

\section{Acknowledgement}

At the conclusion of this manuscript, the author wishes to acknowledge his great indebtedness to Dr. Sumiki Yamamoto for his valuable advice.

\section{References}

1) Merkel KD et al : Supracondylar fracture of the femur afater total knee arthroplasty. J Bone Joint Surgl 68-A : 29-43, 1986.

2) Fujimori $\mathrm{T}$ et al : Supracondylar fracture of the femur following total knee replacement in rheumatoid arthritic patients. Jpn J Rheum Surg 3: 221-225, 1984.

3) Hirsh DM : Supracondylar fracture of the femur following total knee replacement. J Bone Joint Durg $63-\mathrm{A}: 162$ $-163,1981$.

4) Sisto DJ et al : Treatment of Supracondylar fractures following posthetic arthroplasty of the knee. Clin Orthro 196: 265-272, 1985.

5) Mooney $\mathrm{V}$ et al: Cast brace treatment for fractures of the distal part of the femmur. J Bone Joint Surg 52-A : 1563-1578, 1970.

6) Nielsen BF et al: Fracture of the femmur after knee arthroplasty. Acta Orthop Scand 59: 155-157, 1988.

7) Shono E et al: Evaluation of CPM in knee joint. Surgery J Phys Med 1: 58-62, 1990. 
〈和文抄録〉

\title{
Supracondylar Fractre of the femur fracture after total knee arthroplasty TKR 後生じた大腿骨顆上骨折例について
}

\author{
福岡大学整形外科 \\ 生野 英祐・原道也 \\ 蒲 原 光義 - 黒田康二 \\ 高岸直人
}

今日，全人工膝関節置換術 (TKR) は慢性関節りウ マチ (RA) の ADL の向上に有用なものとなっている. しかしながら感染や人工関節のゆるみ等の合併症が問 題となっている，そうした合併症の中で大腿骨顆上骨 折の報告は少ない.

この論文ではわれわれの経験したRA の両側同時 TKR 後に軽微な機転によって生じた右大腿骨顆上骨
折について，主に原因，治療について検討した，原因 としては大腿コンポーネント上部のノッチングや RA に合併した骨粗鬆など考えられた．また治療としては 種々の方法があるが今回の症例では比較的侵襲の少な いラッシュピンによる骨接合術が有用と考えられた。 TKR 後の大腿骨顆上骨折は頻度は低いが留意すべき 合併症であると思われた。 